\title{
Effect of various probiotics on calf performance
}

\author{
J.A. Strzetelski, J. Kowalczyk ${ }^{1}$ and Katarzyna Krawczyk \\ Research Institute of Animal Production, Department of Animal Nutrition \\ 32-083 Balice, Poland \\ 'The Kielanowski Institute of Animal Physiology and Nutrition, Polish Academy of Sciences \\ 05-110 Jabtonna, Poland
}

\begin{abstract}
The effectiveness of different commercial bacterial preparations such as Lactostatic AC and Probios and own preparations, $\mathrm{Bb}$ and $\mathrm{Sf}$ containing Bifidobacterium bifidum (poly-strains) or Streptococcus faecium, on calf performance were investigated in an experiment on 50 calves divided into 5 groups of 10 . Probios and $\mathrm{Bb}$ used as additives to the diet for calves increased their daily body weight gain by an average of 9 and $10 \%$ over the control group ( $\mathrm{P}<0.05$ ), Lactostatic $\mathrm{AC}$ and Sf improved daily gains by 3 and $6 \%$, respectively. A higher growth rate was related to a higher $(8 \%)$ intake of concentrate mixture. A tendency towards higher feed efficiency was observed in calves with higher growth rate.
\end{abstract}

KEY WORDS: probiotics, calves

\section{INTRODUCTION}

The use of bacterial probiotics in animal production has stimulated more interest recently as a possible alternative to antibiotics or anabolics, which provoke anxiety among consumers (Fuller, 1989; Abe et al., 1995). There is a tendency to increase the efficiency of bacterial preparations as stimulators in animal production (Wallace and Newbold, 1992).

The aim of the present study was to estimate the efficiency of some bacterial probiotics of home production and those available on the market.

\section{MATERIAL AND METHODS}

The characteristics of the commercial preparations Lactostatic AC and Probios, or $\mathrm{Bb}$ and $\mathrm{Sf}$ produced by the Institute of Biotechnology of the Agriculture and Food Industry in Warsaw, are presented in Table 1. 
TABLE 1

Characteristics of preparations

\begin{tabular}{llcl}
\hline \multicolumn{1}{c}{ Preparation } & Bacteria culture & $\begin{array}{c}\text { Concentration } \\
\text { of bacteria cells } \\
\text { in 1 g of } \\
\text { preparation }\end{array}$ & \\
\hline $\begin{array}{l}\text { Lactostatic AC } \\
\text { (milk replacer on } \\
\text { dried milk basis) }\end{array}$ & L. acidophillus & $10^{5}$ & Co. Biolacta, Olsztyn \\
Probios & $\begin{array}{l}\text { L. acidophillus, L. casei, } \\
\text { L. plantarium, Streptococcus } \\
\text { faecium }\end{array}$ & $10^{7}$ & "Pioneer" Austria \\
Sf & $\begin{array}{l}\text { Streptococcus faecium } \\
\text { Bb }\end{array}$ & $10^{10}$ & $\begin{array}{l}\text { Institute of Biotechnology } \\
\text { of the Agriculture and Food }\end{array}$ \\
& $\begin{array}{l}\text { Industry, Warsaw } \\
\text { Bifidobacterium bifidum }\end{array}$ & $10^{10}$ & Institute of Biotechnology \\
\hline & $\quad$ & & \\
\hline
\end{tabular}

The experiment was carried out on 50 Black-and-White Lowland bull-calves (with $50 \%$ of HF blood) from day 7 to 80 of life, divided into 5 groups of 10 , completed during 3 months. The control group, $\mathrm{C}$, was fed a basal ration, whereas the diets for the experimental groups were supplemented with one of the following preparations: Lactostatic $\mathrm{AC}$, group L; Probios, group $\mathrm{P}$; Sf, group S; and $\mathrm{Bb}$, group B. Up to day 30 of life the probiotics were given with a milk replacer in the amount of $40 \mathrm{~g} /$ day for group L and $4 \mathrm{~g} /$ day for groups $\mathrm{P}, \mathrm{B}$ and S. After day 30 of life the calves received this amount of probiotics per $\mathrm{kg}$ of concentrate fed.

Pelleted $(\phi 5 \mathrm{~mm})$ concentrate mixture was given to animals ad libitum plus meadow hay $0.10-0.2 \mathrm{~kg} /$ day $/$ head. The concentrate mixture contained $(\%)$ : ground barley, 50; ground wheat, 25; rapeseed oilmeal, 17; wheat bran, 6; mineral mixture, 2 (\%: Premix CJ without antibiotics POZBAC Poznan, 25; limestone, 25; common salt, 15 and commercial mineral mixture $\mathrm{MMB}, 35)$. Calves received 43 $\mathrm{kg}$ of milk replacer Promilk D (Co. LTD Arka) per head in the period of liquid feeding from 7 to 56 days of life. The calves were kept in individual cages with a perforated floor with steady access to drinking water. Body weight was controlled on days 7,56 (after the milk replacer feeding period) and on day 80 as the average of two consecutive days of weighing at the same time in the morning.

The feeding regimen, feed evaluation and balancing of rations were carried out according to the INRA system (IZ, 1997). The nutritive value of milk replacers 
was calculated assuming that in the period of milk feeding the rumen of calves was not fully developed, hence the value of feed degradability in the rumen was nill, $r=0$, and the intestinal digestibility of feed was equal to 0.95 .

The chemical composition of feeds was determined according to AOAC (1990) methods. Statistical analysis was carried out according to the GLM procedure of SAS (1989) software using factorial analysis of variance.

\section{RESULTS AND DISCUSSION}

The concentrate mixture contained $87.3 \%$ dry matter, $16.6 \%$ crude protein and $114 \mathrm{~g}$ PDIN, $111 \mathrm{~g}$ PDIE and $1.0 \mathrm{UFV}$ in $1 \mathrm{~kg}$.

The intake of concentrate in all calves receiving probiotics with their diets was higher, particularly in groups $\mathrm{B}$ and $\mathrm{P}(\mathrm{P}<0.05)$ compared with control animals. This was reflected in higher daily body gains, which in groups $\mathrm{P}, \mathrm{B}, \mathrm{L}$ and $\mathrm{S}$ were $10,9,3$ and $6 \%$ higher than in the control group, respectively (Table 2).

TABLE 2

Body weight, daily body gain, feed and nutrient utilization

\begin{tabular}{lccccrr}
\hline Item & \multicolumn{5}{c}{ Groups } & SE \\
\cline { 2 - 5 } & $\mathrm{C}$ & $\mathrm{P}$ & $\mathrm{L}$ & $\mathrm{Bb}$ & $\mathrm{Sf}$ \\
\hline Body weight, kg: & & & & & \\
$\quad$ initial & 44.2 & 44.9 & 44.9 & 44.7 & 44.0 & 3.00 \\
$\quad$ final & $101.3^{\mathrm{a}}$ & $108.8^{\mathrm{b}}$ & $103.4^{\mathrm{ab}}$ & $107.8^{\mathrm{b}}$ & $104.6^{\mathrm{ab}}$ & 6.22 \\
Daily body gain, g & $783^{\mathrm{a}}$ & $874^{\mathrm{b}}$ & $805^{\mathrm{ab}}$ & $864^{\mathrm{ab}}$ & $830^{\mathrm{ab}}$ & 84.92 \\
Intake of mixture during 73 days & $80.3^{\mathrm{ac}}$ & $85.9^{\mathrm{b}}$ & $81.4^{\mathrm{ac}}$ & $88.6^{\mathrm{b}}$ & $81.7 \mathrm{c}$ & 5.22 \\
$\quad$ concentrate, kg & 1.40 & 1.35 & 1.38 & 1.39 & 1.35 & 0.20 \\
dry matter, $\mathrm{kg}$ & 2.07 & 1.94 & 2.02 & 1.98 & 1.97 & 0.23 \\
crude protein, $\mathrm{g}$ & 418.0 & 394.6 & 409.2 & 400.5 & 400.9 & 34.86 \\
PDI, g & 336 & 311 & 328 & 317 & 319 & 28.16 \\
UFV & 2.33 & 2.20 & 2.28 & 2.23 & 2.23 & 0.13 \\
\hline
\end{tabular}

$\mathrm{a}, \mathrm{b}, \mathrm{c}-\mathrm{P} \leq 0.05$

All probiotic preparations examined in the experiment manifested a beneficial though differentiated effect on feed intake and calf performance. A similarly beneficial effect of probiotics on young and adult ruminants was reported by other authors (Cerna et al., 1991; Bomba et al., 1992; Szulc et al., 1992; Wallace and Newbold, 1992).

The higher growth rate of calves receiving the bacterial preparation Probios containing several species of bacteria or the poly-strain preparation of Bifidobacterium bifidum could be a result of the beneficial influence of the mixture of diffe- 
rent bacteria on bacterial and chemical probiosis of the small intestine (Pusztai et al., 1990) as well as on probiosis of the rumen of older calves after feeding with the milk replacer. Williams and Newbold (1990) and Abe et al. (1995) suggested that applying a poly-strain bacterial preparation augmented the probability that, under given feeding conditions, at least one of the strains reveals a higher effectiveness in the small intestine of animal. A slight increase in body gain of calves receiving Bifidobacterium termophilium, Enterococcus faecium and Lactobacillus acidophillus was reported by Abe et al. (1995).

The results of our experiment demonstrate the usefulness in calf nutrition of the bacterial preparation $\mathrm{Bb}$ which contains various Bifidobacterium bifidum strains. It seems that this preparation, similarly as the recognized commercial preparation Probios containing several species of bacteria, could be an efficient stimulator of growth in calf rearing. However, keeping in mind that the effect of probiotics on animal productivity is usually not completely clear and that bacterial colonization in the intestine is influenced by many factors, further study of this problem is recommended.

\section{REFERENCES}

AOAC, 1990. Association of Official Analytical Chemists. Official Methods of Analysis. 15th Edition. Arlington, VA

Abe F., Ishibashi N., Shimamura S., 1995. Effect of administration of Bifidobacteria and lactic acid bacteria to newborn calves and piglets. J. Dairy Sci. 78, 2838-2846

Bomba A., Kalačnjuk G.J., Lenárt J., Savka O.G., Žitňan R., Gerasimiv M.G., 1992. Dieteticomicrobial stimulation of digestion of the calf rumen (in Czech). Živ. Vyroba 37, 747-754

Černá B., Černý M., Betková H., Patřičný P., Šoch M., Opatrná J., 1991. Influence of PROMA probiotic on calves performance (in Czech). Živ. Vyroba 36, 381-388

Fuller R., 1989. Probiotics in man and animals. J. App. Bacteriol. 66, 365-378

IZ, 1997. Institute of Animal Production. Standards for Cattle, Sheep and Goat Nutritional Value of Feeds for Ruminants (in Polish). Omnitech Press, Warsaw

Pusztai A., Grant G., King T.P., Clarcke E.M.W., 1990. Chemical probiosis. In: W. Haresing, D.J.A. Cole (Editors). Recent advances in animal nutrition. Butterworths, London, pp. 47-60

SAS, 1989. Users Guide, Statistics, Version 6, SAS. Inst. Inc., Cary NC

Szulc T., Zachwieja A., Gawlicz B., 1992. Probiotics Biogen N i Biogen B in the nutrition of cows and calves (in Polish). Prz. hod. 60 (8), 12-15

Wallace R.J., Newbold C.J., 1992. Probiotics for ruminants. In: R. Fuller (Editor). Probiotics - the scientific basis. Chapman and Hall, London, pp. 316-353

Williams P.E.V., Newbold C., 1996. Rumen probiosis: The effects of novel microorganisms on rumen fermentation and ruminant productivity. In: W. Haresing, D.J.A. Cole (Editors). Recent advances in animal nutrition. Butterworths, London, pp. 211-225 